\title{
A protein involved in minichromosome maintenance in yeast binds a transcriptional enhancer conserved in eukaryotes
}

\author{
Steven Passmore, Randolph Elble, and Bik-Kwoon Tye \\ Section of Biochemistry, Molecular and Cell Biology, Cornell University, Ithaca, New York 14853 USA
}

\begin{abstract}
The Saccharomyces cerevisiae MCM1 gene product is a protein with multiple functions. It is a transcription factor necessary for expression of mating-type-specific genes and is also required for the maintenance of minichromosomes. MCM1 shows DNA-binding specificities similar to those of two previously reported DNAbinding factors, pheromone/receptor transcription factor (PRTF) and general regulator of mating type (GRM); like PRTF, its activity can be modulated by the $\alpha 1$ protein. MCM1 binds to the dyad symmetry element $5^{\prime}$ CCTAATTAGG and related sequences, which we refer to as MCM1 control elements (MCEs). MCEs are found within the regulatory regions of a- and $\alpha$-specific genes. Direct and indirect DNA binding assays suggest that a conserved 5'-ATTAGG in one-half of the dyad symmetry element is important for MCM1 binding whereas variants in the other half are tolerated. We have used a novel DNase I 'nicking interference' assay to investigate the interaction of MCM1 with its substrate. These data suggest that MCM1 binds as a dimer, interacting symmetrically with the ATTAGG residues in each half of the binding site. MCM1 contains striking homology to the DNA-binding domain of the human serum response factor (SRF) which mediates the transient transcriptional activation of growth-stimulated genes by binding to the serum response element (SRE). We have shown that MCM1 binds to the human c-fos SRE in vitro and, like other MCEs, the c-fos SRE exhibits MCM1mediated upstream activating sequence (UAS) activity in vivo .
\end{abstract}

[Key Words: MCM1; transcription factor; PRTF; GRM; SRF; mating-type regulation]

Received February 22, 1989; revised version accepted April 14, 1989.

Autonomously replicating sequences (ARSs) are believed to be in vivo origins of replication on plasmids (Brewer and Fangman 1987; Huberman et al. 1987) and on yeast chromosomes (Saffer and Miller 1986). One approach for identifying gene products that may be involved in the initiation of DNA synthesis in Saccharomyces cerevisiae is to isolate mutants that affect the function of ARSs (Maine et al. 1984; Gibson et al. 1986). Previously, we have isolated such mutants, which are known as $\mathrm{mcm}$ for their defect in the maintenance of minichromosomes. Some of these mutants affect the stability of minichromosomes carrying only certain ARSs but not others, suggesting that not all ARSs are regulated similarly (Maine et al. 1984). Recently, we have reported the analysis of the mutant $m c m 1-1$, which was identified originally as an ARS-specific, minichromosome maintenance-defective mutant. It shows a mating defect in $\alpha$ cells that is due to reduced transcription of $M F \alpha 1$ and $S T E 3$, two genes required for the mating of $\alpha$ cells. These results suggest that MCM1 acts as a transcriptional activator of $\alpha$-specific genes (Passmore et al. 1988).

Cell type in yeast is determined by the mating type
$(M A T)$ locus. The $M A T \alpha$ allele encodes two proteins, $\alpha 1$ and $\alpha 2$, which affect the expression of cell-type-specific genes. Genetic and biochemical analyses suggest that the $\alpha 1$ protein is a positive regulator for the transcription of $\alpha$-specific genes (Sprague et al. 1983; Fields and Herskowitz 1985) and the $\alpha 2$ protein is a negative regulator for the transcription of a-specific genes (Wilson and Herkowitz 1984; Hartig et al. 1986). Because the overproduction of MCM1 can complement a mata1 mutation partially, yet expression of MCM1 is independent of the MAT allele (Passmore et al. 1988), it is possible that MCM1 may interact with the $\alpha 1$ protein to activate the transcription of $\alpha$-specific genes. In contrast, a cells containing the $m c m 1-1$ mutation show only a twofold reduction in mating efficiency and a similar reduction in the transcript levels of a-specific genes. The modest effect of mcm1-1 mutation on the expression of a-specific genes may reflect a limited role of $\mathrm{MCMI}$ in the activation of a-specific genes.

Although genetic evidence indicates that the $\alpha 1$ protein is a transcriptional activator of $\alpha$-specific genes, there has been no demonstration of any direct interaction of $\alpha 1$ with DNA from the upstream regions of $\alpha$ - 
specific genes. In searching for a cofactor of the $\alpha 1$ protein, Bender and Sprague (1987) identified a DNAbinding activity in yeast extracts called the pheromone/receptor transcription factor (PRTF), which binds to the upstream region of $\alpha$-specific genes but only in the presence of the $\alpha 1$ protein. In contrast, PRTF can bind to a-specific genes in the absence of $\alpha$ l. At the same time, Keleher et al. (1988) identified a DNA-binding factor general regulator of mating (GRM), which binds cooperatively with the $\alpha 2$ protein to operator sites of aspecific genes. Mutations in the GRM-binding sites within synthetic operators result in the derepression of downstream reporter genes, suggesting that GRM acts as a corepressor with the $\alpha 2$ protein. Interestingly, the activities of PRTF and GRM are found in all cell types and the sequence motif recognized by PRTF is similar to that recognized by GRM, which suggests that these two factors may, in fact, be the same. It was proposed that PRTF/GRM acts both as a coactivator with $\alpha 1$ in the regulation of $\alpha$-specific genes and a corepressor with $\alpha 2$ in the repression of a-specific genes in $\alpha$ cells (Bender and Sprague 1987; Keleher et al. 1988).

The phenotypes of the mcm1-1 mutant are consistent with those expected of a mutant defective in PRTF/ GRM except that derepression of a-specific genes was not observed in $\alpha$ cells containing the mcm1-1 mutation (Passmore et al. 1988). To investigate the relationship between MCM1 and PRTF/GRM, as well as the possibility that MCM1 may bind to ARSs in its role in plasmid maintenance, it was of interest to carry out a detailed analysis of the binding speficities of MCMI. In this paper we present evidence suggesting that MCM1 acts directly as a transcriptional activator of cell-typespecific genes. We have shown that the amino-terminal 188-amino-acid portion of the MCMl protein expressed and purified from Escherichia coli binds to the upstream regulatory elements of a and $\alpha$-specific genes. DNase I protection experiments indicate that the DNA-binding specificity of MCMl is very similar to that of PRTF and GRM.

MCM1 is an essential gene that is expressed in all cell types (Passmore et al. 1988). It encodes a protein of 286 amino acids containing striking homology to the human serum response factor (SRF) (Norman et al. 1988) and another yeast regulatory protein, encoded by $A R G 80$ (Dubois et al. 1987), located 700 bp upstream of MCM1 (Passmore et al. 1988). Further analysis of the binding specificity of MCM1 reveals that it will bind to a 14-bp element called the serum response element (SRE) (Treisman 1986), which is used by higher cells to control genes in response to growth factors. This response is mediated through the action of SRF, which binds to the SRE. We show that the human c-fos SRE inserted in front of a reporter gene serves as an upstream activating sequence (UAS), which is responsive to the level of MCM1 in yeast. Thus, it appears that these two homologous transcription factors, MCMl and SRF, of fungal and mammalian origins, respectively, recognize a conserved DNA element. Possible analogous functions served by these two transcription factors in their respective systems are discussed.

\section{Results}

The MCM1 gene product is necessary for the efficient transcription of certain cell-type-specific genes and is also required for growth. MCM1 encodes a protein of 286 amino acids containing an unusually acidic region in which 19 of 20 residues are glutamic acid or aspartic acid. Polyanionic regions are characteristic of transcription activators (Hope and Struhl 1986; Keegan et al. 1986), suggesting that MCM1 may act to effect transcription by presenting this domain to the transcription machinery. We have begun a biochemical analysis of the MCM1 protein to determine whether the MCM1 protein mediates its effect on transcription directly by binding DNA-regulatory elements. We have overproduced and purified from $E$. coli a fusion protein containing the amino-terminal 188-amino-acid portion of the MCM1 protein. This region of the protein has been shown in vivo to contain all of the functions necessary for transcription of $\alpha$-specific genes, minichromosome maintenance, and viability (Passmore et al. 1988).

\section{Overproduction of a hybrid $\phi-10-M C M 1$ protein}

A chimeric gene that contains a 575-bp BamHI-EcoRI fragment encoding the amino terminus of the MCM1 protein was fused in-frame to the gene encoding the phage T7 $\phi-10$ coat protein borne on the plasmid pETMCM1 (1-188) (Fig. 1A). The amino terminus of this fusion protein contains 13 amino acids from the $\phi-10$ protein followed by 6 amino acids coded for by the region just upstream of the $M C M 1$ open reading frame (ORF) and then 188 amino acids of the MCM1 protein (Fig. 1B). The $\phi$-10-truncated MCM1 fusion protein [MCM1 (1-188)] was overexpressed in an E. coli strain harboring pETMCM1 (1-188). Lysates were prepared and fractionated as described in Experimental procedures. The MCM1 $(1-188)$ used for the DNA-binding studies is shown in the left panel of Figure 1C. On the basis of Coomassie blue staining of the gel, we estimate that at least $30 \%$ of this protein preparation is MCMl (1-188). The right panel of Figure 1C shows a Western blot of the purified protein developed with a polyclonal anti-MCM1 antibody. The MCM1 (1-188) truncated protein has an apparent molecular weight of about 29 $\mathrm{kD}$, which is higher than its expected molecular weight of $21 \mathrm{kD}$, presumably due to its polyacidic tract (Earnshaw et al. 1987). In fact, the full-length protein also has an anomalous apparent molecular weight of $42 \mathrm{kD}$ (data not shown). The second band apparent in the Western blot is a proteolytic fragment of MCM1 $(1-188)$ and accounts for $\sim 10 \%$ of the total immuno-cross-reactive material.

\section{MCM1 binds to the UASs of MF $\alpha 1$}

Because mutations in $M C M 1$ can lead to a decrease in transcription of the $M F \alpha 1$ gene, we examined the ability of the MCMl protein to interact with the regulatory region of this gene using a DNase I protection assay. Endlabeled $M F \alpha 1$ DNA from the 5'-upstream region was digested partially with pancreatic DNase I in the presence 
A

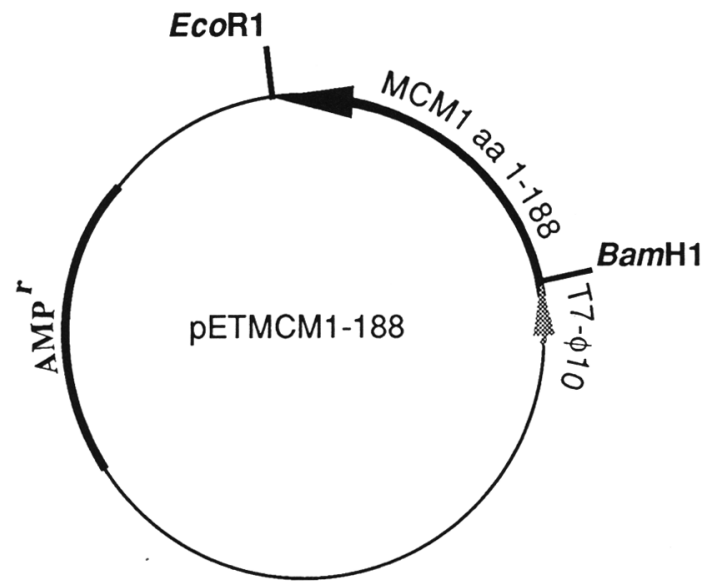

C

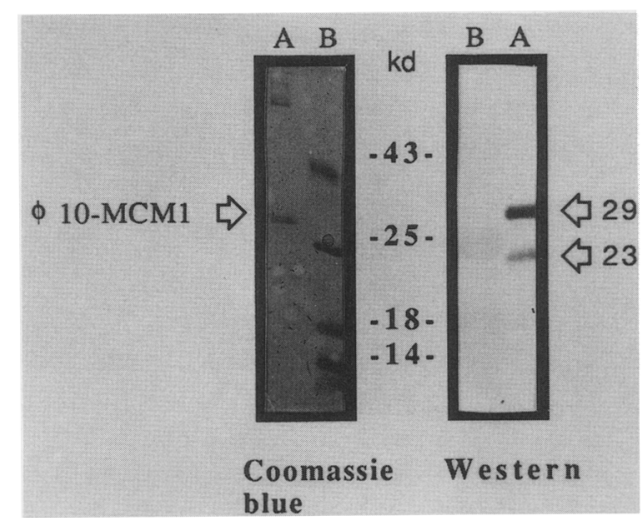

B

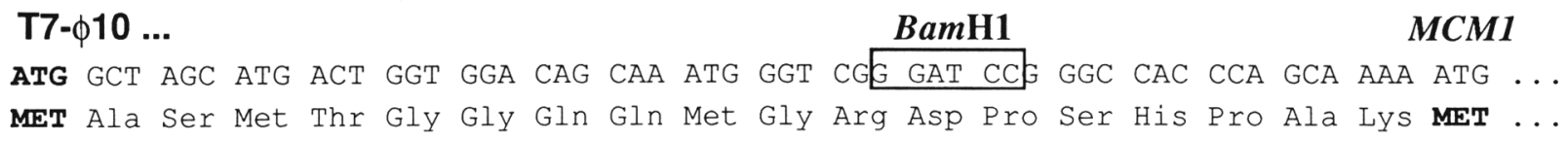

Figure 1. Expression and purification of the MCM1 fusion protein. $(A)$ Plasmid that contains the truncated $M C M 1$ gene fused in-frame to the amino terminus of the T7- $\phi 10$ gene. $(B)$ DNA and protein sequence of the amino terminus of the fusion protein. Fusion is achieved by ligation of the two genes at the BamHI site which is $18 \mathrm{bp} 5^{\prime}$ to the ATG of the MCM1 ORF and 39 bp $3^{\prime}$ to the ATG of the T7- $\phi 10$ protein. $(C$, Left) Purified MCMl (1-188) on SDS-PAGE stained with Coomassie blue. (Right) Western blot of purified MCM1 (1-188). (Lanes B) Molecular weight markers; (lanes A) partially purified MCM1 (1-188).

of varying amounts of the purified MCM1 (1-188) (Fig. 2). The three regions of the promoter protected from DNase I digestion by MCM1 $(1-188)$ are shown. Each footprinted region contains a sequence motif related to the 10-bp dyad symmetry element CCTAATTAGG. Two of these regions correspond to $M F \alpha 1$ UAS2 (proximal UAS) and UAS1 (distal UAS), the two $M F \alpha 1$ UASs that require $\alpha 1$ protein for activity, and are silent in diploid cells (Inokuchi et al. 1987).

The sequence of the footprinted region nearest the $M F \alpha 1$ mRNA start site is shown in Figure 2. The footprint of the coding strand covers $\sim 30 \mathrm{bp}$, with the most strongly protected region near the center (solid bar). This region corresponds to the 10 -bp dyad symmetry element CCTAATTAGG. The protected region extends beyond the symmetry element $\sim 10 \mathrm{bp}$ on either side /stippled bars|, and is punctuated by DNase I-sensitive sites. MCM1-induced DNase I-sensitive sites also are observed within and between the footprinted regions (arrowheads in Fig. 2). The position and extent of the footprints that result from the binding of MCM1 (1-188) to the UASs of $M F \alpha 1$ are similar to those footprinted by PRTF in the presence of $\alpha 1$ (Bender and Sprague 1987). Although Bender and Sprague showed that the PRTF activity in cell extracts requires the $\alpha 1$ protein for binding to the MFo1 UAS, we have shown here that MCM1
$(1-188)$ purified from $E$. coli binds to this substrate without the aid of any additional yeast proteins. Bender and Sprague suggested that the large region footprinted by PRTF in the presence of $\alpha 1$ was due to the simultaneous binding of PRTF and $\alpha 1$ to the MF 1 UASs, interacting with sites $P$ and $Q$, respectively. However, we have shown that MCM1 alone footprints the central region of the P site, the MCM1 control element (MCE), as well as a portion of the $Q$ site. The difference in their requirements for $\alpha 1$ may be due to the choice of carrier DNA used in these experiments.

MCM1 binds to the upstream-regulatory sequences of both a- and $\alpha$-specific genes

Sequences similar to the dyad symmetry elements present upstream of the MF $\alpha 1$ coding region are also found within the operators of the a-specific genes, STE2 and STE6 (Fig. 3B). To determine whether MCM1 $(1-188)$ is capable of binding both a- and $\alpha$-specific UASs, we used a gel retardation assay to monitor its binding. This assay was tested first on the natural sequences of the MFo1 promoter. When MCM1 (1-188) and labeled $M F \alpha 1$-UAS1 or MF 1-UAS2 were mixed in the presence of excess poly[d(I-C)] and then fractionated on a native polyacrylamide gel, slowly migrating pro- 


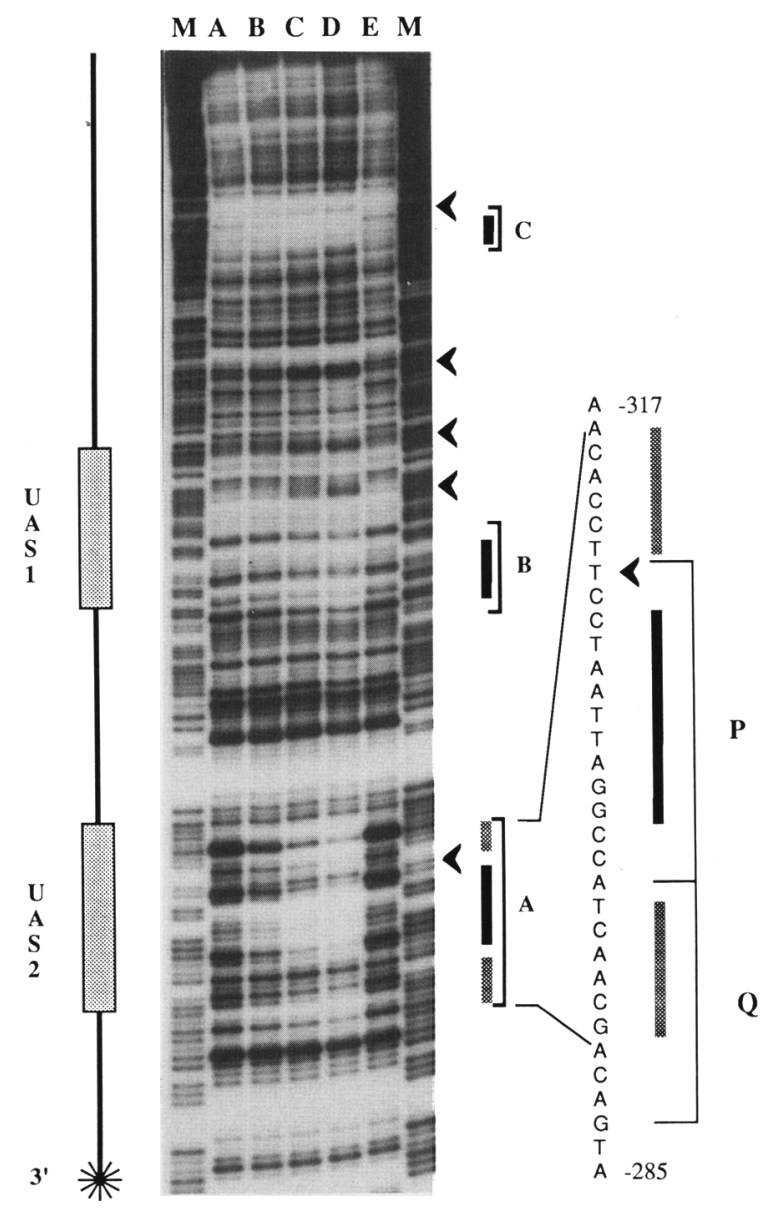

Figure 2. MCM1 $(1-188)$ protects three related regions of the $M F \alpha 1$ promoter from DNase I digestion. The coding strand of the $M F \alpha 1$ promoter was $3^{\prime}$-end-labeled and then incubated with MCMI (1-188). (Lanes $A-D)$ DNase I digestion patterns observed in the presence of increasing amounts of MCM1 (1-188). The amount of MCM1 (1-188) increases by threefold between lanes. (Lane $E$ ) DNase I digestion pattern observed in the absence of MCMl (1-188); (lanes $M$ ) Maxam-Gilbert chemical sequence ladders. Brackets indicate regions footprinted by MCM1 $(1-188)$. The sequence of the proximal MCM1-binding site in the $M F \alpha 1$ promoter and its position from the transcriptional start site are shown. Vertical black bars indicate the location of the MCEs /CCTAATTAGT and CCGAATTAGG) within these regions. Arrowheads mark the positions of DNase I hypersensitive sites.

tein-DNA complexes were observed (Fig. 3A). Both UAS elements formed complexes with MCM1 (1-188), and in each case we saw multiple retarded bands. The STE2 promoter also was able to form complexes with MCM1 (1-188), giving a similar pattern of multiple bands (Fig. 3A). Oligonucleotides corresponding to the dyad symmetry element $\left(\mathrm{DSE}_{14}\right)$, or the related 'core' element found within the STE6 promoter (STE6-o), were cloned into a polylinker site on a plasmid (sequences of the oligonucleotides are shown in Experimental procedures). The vector DNA without the oligonucleotide insert did not serve as a substrate for MCM1 (1-188) (Fig.
3A, lanes 1 and 2). However, when DNA fragments containing DSE ${ }_{14}$ or STE6-o were used in these assays, we found that they were good substrates for MCM1 (1-188) (Fig. 3A, lanes 10 and 12), indicating that the DSE ${ }_{14}$ or STE6-o elements were sufficient for binding.

The interaction of MCM1 with the regulatory region of the STE2 gene was localized by footprinting analysis (data not shown). MCM1 was found to footprint the region of the STE2 operator that contains MCE, the sequence motif related to the MCMl-binding site found upstream of $M F \alpha 1$. We noted that the interaction of MCM1 with the STE2 operator is similar to that of GRM with the STE6 operator (Keleher et al. 1988; Sauer et al. 1988).

\section{$\alpha 1$ enhances binding of MCM1}

If MCM1 is in fact the same as PRTF, then its binding to the UASs of $\alpha$-specific genes should be enhanced by the $\alpha 1$ protein. We have shown previously that overexpression of the MCM1 protein in a mato1 mutant can suppress the mating defect of this strain partially, suggesting that MCMl and the $\alpha 1$ protein may interact with each other (Passmore et al. 1988). A direct demonstration that $\alpha 1$ enhances the binding of MCM1 is shown by the titration of MCM1 (1-188) against a fixed concentration of DNA substrate, in the presence or absence of $\alpha 1$ protein. At a concentration of MCMl $(1-188)$ where binding to its substrate is no longer observable, addition of partially purified $\alpha 1$ protein expressed in E. coli (a kind gift from E. Grayhack) was found to enhance the binding of MCM1 to UAS2 of $M F \alpha 1$. This can be seen by comparing the amount of shifted material in the PAGE-retardation assay shown in Figure 4A, lanes 4 and 5. Both lanes contain the same amount of MCM1, but lane 5 contains in addition $\alpha 1$ protein in an approximately equal molar amount.

To verify that MCM1 was responsible for the formation of the slowly migrating protein-DNA complexes observed in the gel-retardation assays described above, MCM1-specific antiserum was added to several control reactions. The MCM1 protein could be detected in the retarded complex whether in the presence or absence of the $\alpha 1$ protein, as shown by the formation of a ternary antibody-MCM1-DNA complex (Fig. 4A, lanes 7 and 8). This complex is observed when antibody specific to MCM1 is used, but not with the preimmune serum (Fig. $4 \mathrm{~A}$, bottom panel). We do not see any change in the migration of the retarded bands in the presence of the $\alpha 1$ protein (Fig. 4, cf. lanes 7 and 8), nor do we see an $\alpha 1$ DNA complex in the absence of the MCM1 protein (Fig. 4, lane 6).

To examine more closely the effect of $\alpha 1$ on the interaction of MCM1 with MFo1-UAS2, we used a DNase I-footprinting assay. The results of such an experiment using a synthetic oligonucleotide (MF $\alpha 1$ p60) containing MFo1-UAS2 are shown in Figure 4B. As might have been expected from the failure of the $\alpha 1$ protein to form a complex detectable using the gel-retardation assay, the $\alpha 1$ protein alone did not yield a footprint on the $M F \alpha 1$ - 

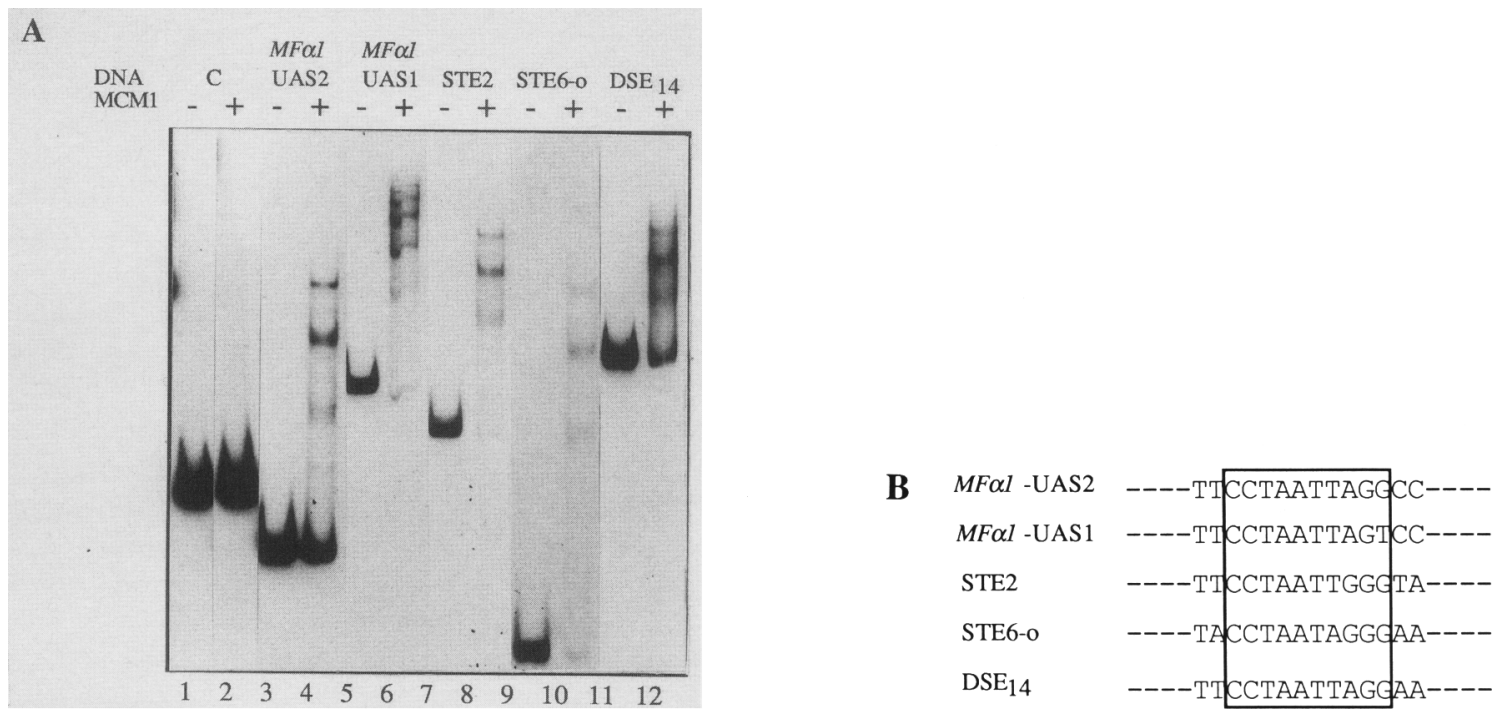

Figure 3. MCMl binds to the regulatory regions of both a- and $\alpha$-specific genes. $(A)$ The binding of MCMl to its substrates was visualized by PAGE-retardation assay. DNA substrates are ${ }^{32}$ P-labeled. (C) Control DNA; 187-bp PvuII-HindIII fragment from BluescriptKS. Odd-numbered lanes contain DNA $(\sim 1 \mathrm{fmole})$ alone $(-)$ and even-numbered lanes contain both DNA substrate and 2 ng of MCM1 protein (+1, except for lane 2 which has $5 \mathrm{ng}$. (MF 1 1-prox) A 131-bp HindIII-XmnI fragment from pKSMF $\alpha$ l; (MFal-dist) 270-bp BamHI-XmnI fragment from pKSMFo1; (STE2) 336-bp HindIII fragment from the upstream region of STE2; (STE6-o) 79-bp HindIII-EcoRI fragment from the plasmid pI; (DSE) 328-bp BamHI-PvuII fragment from pKSMCE. $(B)$ Nucleotide sequences of the synthetic oligonucleotides and the MCE-like region from the $M F \alpha 1$ and STE2 upstream region.

UAS2 sequence (Fig. 4B,lane C). However, the binding of MCM1 to MFa1-UAS2 was enhanced by the presence of $\alpha 1$, as revealed by a decrease in the intensity of the bands throughout the footprinted region and an extension of the footprint by about $4 \mathrm{bp}$ in the Q region (Fig. $4 \mathrm{~B}$, cf. lanes $\mathrm{C}$ and $\mathrm{D}$, lanes $\mathrm{E}$ and $\mathrm{F}$ ), the proposed site of action of $\alpha 1$ (Bender and Sprague 1987). Similar effects were observed when the EcoRI-BamHI fragment containing the natural $M F \alpha 1$ upstream sequence from pKSMF $\alpha 1$ was examined (data not shown). These results may be due to a more complete occupancy by MCM1 in the presence of $\alpha 1$ or due to a different DNA-protein complex formed by the simultaneous binding of MCM1 and $\alpha 1$. To distinguish between these possibilities, we examined the MCM1-dependent DNase I protection pattern of gel-purified MCM1-MFo1-UAS2 complexes $\left(C_{1}\right.$ and $\left.C_{2}\right)$ that had been separated on a polyacrylamide gel after treatment with DNase I. The pattern of DNase I protection from these gel-purified complexes should represent the maximum possible occupancy by MCM1 alone. The DNase I protection pattern from these complexes was determined by densitometric tracing (data not shown) and found to be the same as that afforded by MCM1 alone in solution (cf. Fig. 4C, lanes $C_{1}$ and $C_{2}$ with Fig. 4B, lanes $B$ and E). Thus, it appears that the presence of $\alpha 1$ results in both an increase in the occupancy by MCM1 and the formation of a complex that interacts with an extended region of the MF $\alpha 1$ promoter that now spans all of the $\mathrm{Q}$ site as well as the $\mathrm{P}$ site. These results suggest that MCM1 and $\alpha 1$ bind cooperatively to the UASs of $\alpha$-specific genes. In addition, the isolated complexes $C_{1}$ and $C_{2}$ had indistinguishable
DNase I protection patterns for both the coding strand and the noncoding strand (Fig. 4C) suggesting that MCM1 interacts with the DNA in the different complexes in a similar manner.

\section{MCM1 binding site specificity}

To examine the DNA-binding specificity of the MCM1 protein in more detail, we used a number of variant dyad symmetry elements in a competition assay to determine the relative affinity of MCMI $(1-188)$ for its substrates (Fig. 5). As competitor DNA, oligonucleotides corresponding to the MCEs of MF 1 (UAS1) and STE2 were synthesized. In addition, oligonucleotides corresponding to variants of the dyad symmetry element that contain symmetric double mutations were synthesized and polymerized. These variants have either altered end-to-end spacing $(+2$ and -2$)$ that changes half of the MCE, or altered internal AT sequences, but all exhibit dyad symmetry (Fig. 5B). A polymer of the oligonucleotide CCTAATTT, which contains only the first $7 \mathrm{bp}$ of the MCE, was also included in these studies.

Cold competitor DNA was added to a reaction mix followed by MCM1 (1-188) and a labeled HindIII fragment containing the STE2 UAS. The reaction mixture was separated by PAGE. The ability of an oligonucleotide to compete was indicated by the amount of unbound labeled STE2 UAS (Fig. 5A). The affinity of MCM1 (1-188) for these different MCE-like sequences in decreasing order was: $\mathrm{DSE}_{14}>\mathrm{CCTAAT}, \mathrm{MF} \alpha \mathrm{d}-\mathrm{o}$, STE2-o $>$ T3A, A4T, A5T $>+2,-2$. These results indicate that the actual sequence of the 6 ATs in the middle 


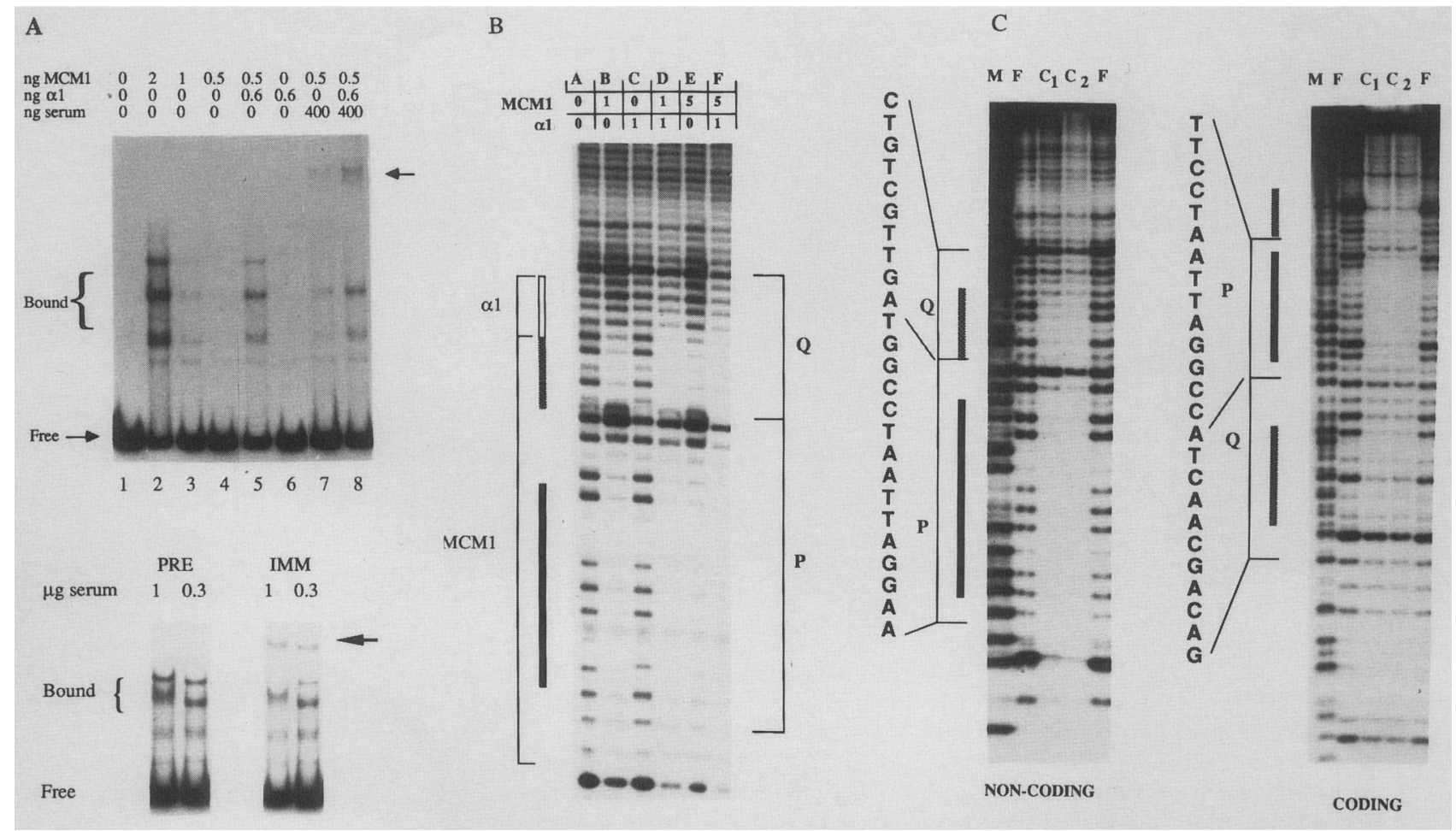

Figure 4. $\alpha 1$ enhances binding of MCM1 $(1-188)$ to the MF $\alpha 1-U A S 2$ and affects the extent of the footprinted region. $(A)$ (Top) Gel-retardation assay using purifed MCM1 (1-188). The EcoRI-XmnI fragment containing MF $\alpha 1$-UAS2 was incubated with the indicated amounts of MCM1 and/or $\alpha 1$ protein. The arrow on the right indicates the position of the antibody-MCM1-DNA complex formed by addition of immune serum to the binding reaction after a 10-min incubation. (Bottom) Antibody control, in the presence of preimmune serum (left) and MCM1-specific antiserum (right). (B) DNase I protection assay of MFo1-UAS2 in the presence and absence of $\alpha 1$. The oligonucleotide MFolp60 was labeled on the noncoding strand and then incubated with MCM1 and/or $\alpha 1$ protein prior to DNase I digestion. The amounts of each of the proteins added are indicated in microliters above each lane. $\mathrm{P}$ and $\mathrm{Q}$ are binding sites for PRTF and $\alpha 1$, respectively, proposed by Bender and Sprague (1987). (C) DNase I protection pattern of MCM1/MF 1 1-UAS2 complexes. MFo 1 p60 was labeled on either the coding or the noncoding strand. Labeled $M F \alpha 1$ and MCM1 were incubated and then digested with DNase I. MF $\alpha$ lp60/MCMl complexes were isolated using the gel-retardation system. (Lanes $M$ ) Maxam-Gilbert G+A sequence ladders; (lanes $F$ ) DNA digested in the absence of MCM1 protein; (lanes $C_{1}$ ) the more abundant, intermediate mobility complex; (lanes $C_{2}$ ) the more slowly migrating complex.

strongly affects the binding affinity of MCM1. We noticed that all of the natural binding sites have on the left side of the MCE one copy of the sequence CCTAAT while deviations occur in the right half. Furthermore, the CCTAAT polymer (CCTAATTT) ${ }_{n}$ competed very well for the binding of MCM1 $(1-188)$ in these assays. This half-site effect is often seen in the case of dyad symmetry elements. We propose, based on these direct and indirect binding data, that the optimum site for the binding of MCM1 $(1-188)$ is the perfect dyad symmetry element CCTAATTAGG.

\section{Interaction of MCM1 with its binding site}

We have used the nicks introduced by DNase I as the basis for a DNA-binding interference assay (nicking interference). DNase I in the presence of $\mathrm{Mg}^{2+}$ and $\mathrm{Ca}^{2+}$ introduces single-stranded nicks in double-stranded DNA. The phosphodiester bond is hydrolyzed, producing 5 ' phosphate and 3 ' hydroxyl groups. Because the region of the $M F \alpha 1$ promoter that can be footprinted by MCM1 can be cleaved at almost every base by DNase I, we decided to make use of nicks introduced by DNase I in a binding-interference assay.

A synthetic oligonucleotide containing UAS2 (MF $\alpha 1 \mathrm{p} 60)$ from the promoter of $M F \alpha 1$ was end-labeled and then nicked with DNase I. This collection of nicked DNA was incubated with excess MCM1 protein and allowed to bind. To identify the nicks that interfere with binding, the bound and unbound fractions were separated using the gel-retardation system and then examined on a sequencing gel (Fig. 6). Nicks that interfere with binding would be expected to be depleted from the bound fractions and enriched in the nonbound fractions. Within the limits of this method, namely the nonrandom cutting by DNase I, the pattern of nicking inhibition appeared symmetrical. Nicks introduced in the MCE $5^{\prime}$ to $T_{3}, A_{4}, A_{5}, T_{6}, T_{7}, A_{8}, G_{9}, G_{10}$, or $C_{11}$ were found to reduce binding of MCM1. Furthermore, nicks introduced $5^{\prime}$ to $A_{5}, T_{6}, A_{8}, G_{9}$, or $G_{10}$ abolished binding. Results of DMS-interference assays are consistent with those of nicking interference assays, indicating that MCM1 interacts with $G_{9}$ and $G_{10}$ on both strands in the 
A.

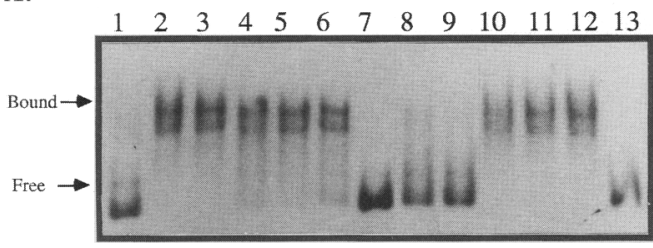

B.

\begin{tabular}{|c|c|c|}
\hline Lanes & Name & Sequence \\
\hline 1. & ССТАAТ & 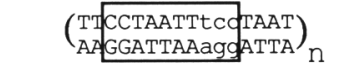 \\
\hline 2 . & +2 & $\left(\begin{array}{l}\text { Tr CCTAAaTttäGGAA } \\
\text { AA GGATTtAaatCCTT }\end{array}\right)_{n}$ \\
\hline 3. & -2 & $\left(\begin{array}{l}\text { Try CCTAtaggaa } \\
\text { AAGGATatcct }\end{array}\right)_{n}$ \\
\hline 4. & $\mathrm{~T} 3 \mathrm{~A}$ & 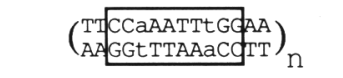 \\
\hline 5. & $\mathrm{~A} 4 \mathrm{~T}$ & $\left(\begin{array}{l}\text { TTCCTLATaAGGAA } \\
\text { AAGGAaTAtTCOTT }\end{array}\right)_{n}$ \\
\hline 6. & A5T & $\left(\begin{array}{l}\text { TT CCTAtaTAGGAA } \\
\text { AAGGATatATCOTT }\end{array}\right)_{n}$ \\
\hline 7. & $\mathrm{DSE}_{14}$ & 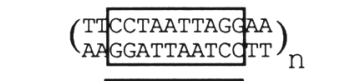 \\
\hline 8. & $\mathrm{MF} \alpha \mathrm{d}-\mathrm{O}$ & $\begin{array}{l}\text { CCGGGT } \text { CCTAATTAGECCATGCA } \\
\text { GGCCCAAGGATTAATCaGGTACGT }\end{array}$ \\
\hline 9. & STE2-O & $\begin{array}{l}\text { CCGGGTT CCTAATTgGGGTATCGA } \\
\text { GGCCCAA GGATTAACCDCATAGCT }\end{array}$ \\
\hline \multicolumn{3}{|c|}{ 10. $(d I: d C)_{n}$} \\
\hline \multicolumn{3}{|c|}{$11 \cdot(d I: d C)_{n}$} \\
\hline 12 & (dI : dC & \\
\hline
\end{tabular}

Fold- relative excess competition 100 100 100
$+$

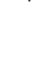

$-$

$-$

$+1-$

$+1-$

$+1-$

$+$

$+$

$+$

-

$-$

$-$

-
Figure 5. Competition for the binding of MCM1-188 to STE2 UAS by different mutant binding sites. (A) PAGE-retardation assay. Labeled STE2 DNA ( $1 \mathrm{fM}$ ) and $5 \mathrm{ng}$ of MCM1 (1-188) were used in each of these assays. Cold competitor DNA (100 $\mathrm{fm}$ of binding sites) was added to the reaction before addition of labeled DNA substrate. Oligonucleotides (24-mer) were annealed and used directly. Polymers of shorter oligonucleotides were formed as described in Experimental procedures. The reaction also contains $20 \mathrm{ng}$ of poly[d(I-C)]. (Lanes 10, 11, and 12) Contain 1000,120 , and $30 \mathrm{ng}$ of poly[d(I-C) respectively; (lane 13) contains no MCM1 (1-188). (B) DNA sequence of the cold competitor DNA containing the variant sites, the fold molar excess of the cold competitor DNA to labeled DNA, and their relative affinity to MCM1 $(1-188)$ as determined by competition shown in $A$. major groove and that these contacts are essential for binding (Fig. 6, only noncoding strand is shown). Because these symmetric nicks can eliminate binding, MCM1 probably interacts with its symmetric binding site as a dimer, contacting ATTAGG on both strands. The localized nature of the nicks that eliminate binding argues against any major structural change. We cannot determine from these results whether the residues identified as important are involved in phosphate- or basespecific interactions with MCM1.

\section{MCM1 binds to genes involved in the transition from the resting state to proliferative state in yeast and mammals}

We noticed that a sequence motif used by higher cells to control genes in response to growth factors resembles the MCM1 control element. Transcription of the human c-fos gene is responsive to serum, and is stimulated to high levels within $5 \mathrm{~min}$ after addition of serum or certain growth factors found in serum (Treisman 1985). This effect is mediated by a DNA element with dyad symmetry found in the c-fos promoter, the SRE (Treisman 1987). This sequence binds a protein, the SRF, which has been isolated from human cells (Prywes and Roeder 1987; Treisman 1987).

We tested the mammalian c-fos variant of SRE, CCTAATATGG, for its ability to bind MCM1. The sequence of this element closely resembles the MCE. Figure 7A shows the results of a gel-retardation experiment demonstrating that an oligonucleotide corresponding to the human c-fos SRE is able to bind to MCM1 (1-188) (Fig. 7A, lane 2). This SRE was able to form DNA-protein complexes with MCM1 $(1-188)$ and gave rise to a multiple-banding pattern similar to that seen for the MCM1-binding sites derived from STE6 (Fig. 7A, lane 11) and STE2 (see Fig. 2). Slower migrating antibody-DNA-protein complexes were formed when anti-MCM1 antiserum was added (Fig. 7A, lanes 3 and 12) but not with the addition of preimmune serum (Fig. $7 \mathrm{~A}$, lane 4), which indicated that MCM1 (1-188) was responsible for binding to the labeled substrate in each case. We have also shown that addition of a polymer of the $\mathrm{DSE}_{14}$ sequence competes for the binding of MCM1 
Figure 6. Modifications within the sequence ATTAGG inhibit binding of MCM1. MF $\alpha 1 \mathrm{p} 60$ was 3 '-end-labeled on either the coding or noncoding strand using the Klenow fragment of DNA polymerase I. The labeled MF $\alpha 1$ p60 was either nicked by DNase I or methylated by dimethylsulfate. MCM1 protein then was allowed to bind to the modified DNA, and the collection of bound and nonbound DNA was fractionated using a gel-retardation system. (Lanes $M$ ) Maxam and Gilbert sequence size standards; (lanes $A$ ) input DNA for the preparative gel separation; (lanes $B$ and $C$ ) bound and nonbound fractions, respectively, isolated from the gel. The bases of the MCE are numbered starting with its most $5^{\prime}$ C. The sequence of the region in which nicks inhibit binding is shown in the center of the figure; the position of methylated Gs that inhibit binding are indicated by circles. Note: DNase I cleavage of phosphodiester bond $5^{\prime}$ to $\mathrm{G}_{9}$ comigrates with $G_{10}$ in Maxam and Gilbert sequence marker.

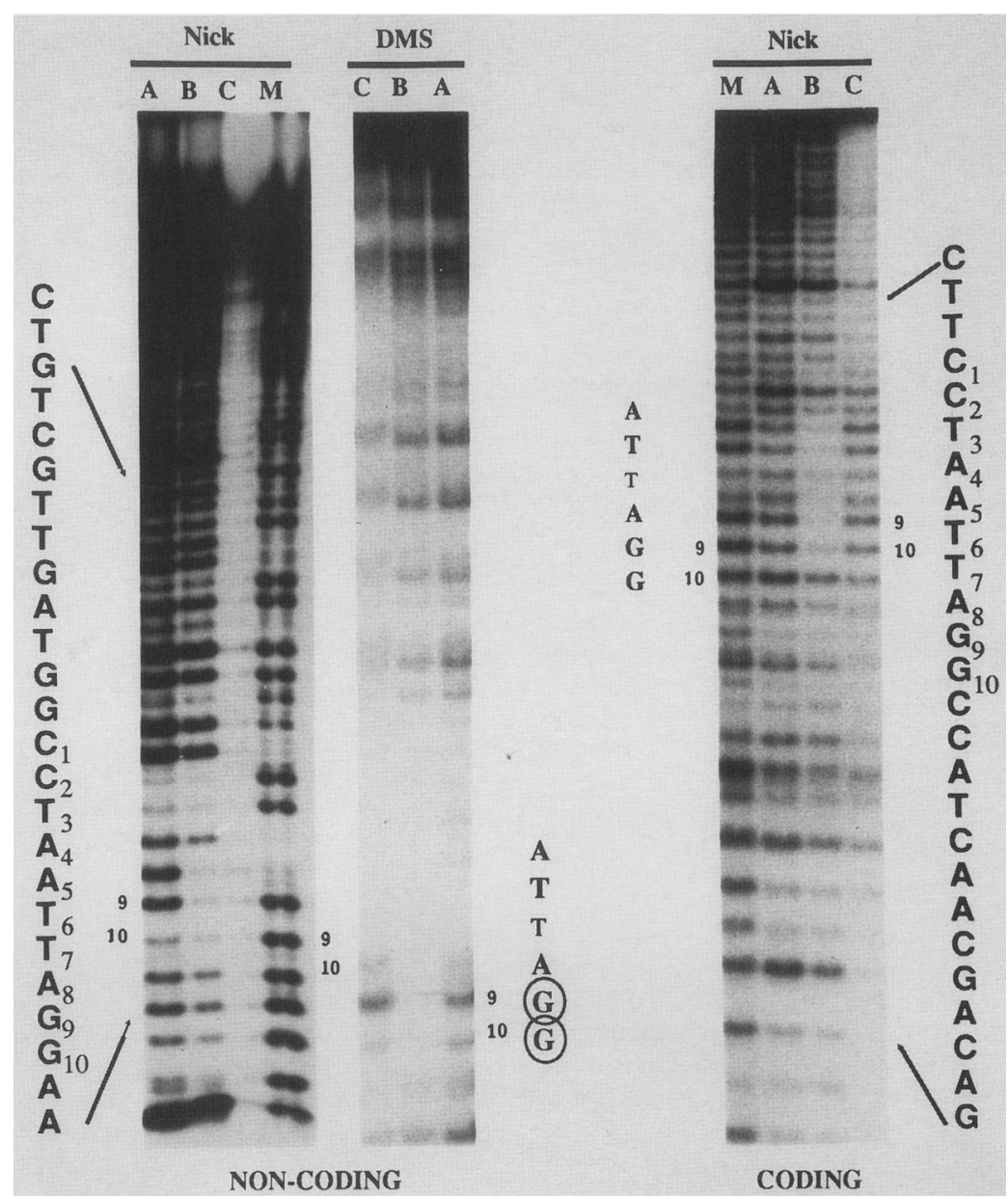

to its substrates (Fig. 7A, lanes 5 and 6). Recently, Hayes et al. $\{1988\}$ have observed a DNA-binding activity in yeast extract that binds to the mammalian c-fos SRE.

A search for MCE sequences in front of known yeast genes revealed that similar sequences occur upstream of several genes, including CDC31 (Baum et al. 1986), a gene necessary for spindle pole body duplication, and CDC28 (Lorincz and Reed 1984), a gene that encodes a protein kinase involved in the control of cell-cycle progression from $G_{1}$ to $S$ phase. The MCE found upstream of the CDC28 gene occurs at position -142 relative to the transcript start site, a plausible location for a UAS. A 26-mer oligonucleotide corresponding to the upstream region of $C D C 28$ containing the MCE-like sequence was synthesized and tested for binding to MCM1-188. As shown in Figure 7A, MCM1 $(1-188)$ also binds to the MCE upstream of $C D C 28$, giving rise to multiple bands, and addition of anti-MCM1 antibody results in further retardation of the MCM1 (1-188)-DNA complex (Fig. $7 \mathrm{~A}$, lanes 91.

Figure $7 \mathrm{~B}$ shows the sequence of the consensus $\mathrm{MCE}$ as well as the related binding sequences from STE2 and STE6. The c-fos SRE sequence contains the CCTAAT motif, which is entirely conserved in the MCE sites of aand $\alpha$-specific genes and shows strong binding to MCM1 (1-188).

\section{The human $c$-fos SRE acts as a UAS in yeast}

The binding of MCM1 to the human c-fos SRE prompted us to test whether the human c-fos SRE and other CCTAAT-containing elements can serve as UASs, and if so, whether this activity is mediated through the MCM1 protein. To do so we monitored the $\beta$-galactosidase activity expressed from a STE2-lacZ fusion protein. The upstream regulatory sequence (URS) of the STE2 gene is contained within a HindIII fragment that can be removed and replaced with other DNA sequences (Smith 1986). DNA sequences containing either DSE ${ }_{14}$ or the c-fos SRE were placed upstream of the TATA sequence of the STE2-lacZ gene fusion (Fig. 8A).

The $\beta$-galactosidase activity of the STE2-lacZ fusion gene bearing an intact upstream regulatory region (CD14) is $41 \mathrm{U} / \mathrm{mg}$ of protein in $\alpha$ cells and $1791 \mathrm{U} / \mathrm{mg}$ of protein in a cells (Fig. 8B). This low activity in $\alpha$ cells and high activity in a cells is expected for an a-specific gene whose transcription is regulated by the $\alpha 2$ protein. We show that the expression of STE2 can be modulated by MCM1. When a high-copy-number plasmid containing the MCM1 gene was introduced into these strains, we found that the increased MCM1 concentration enhanced the expression of the STE2-lacZ fusion protein in a cells approximately twofold, but had no ef- 


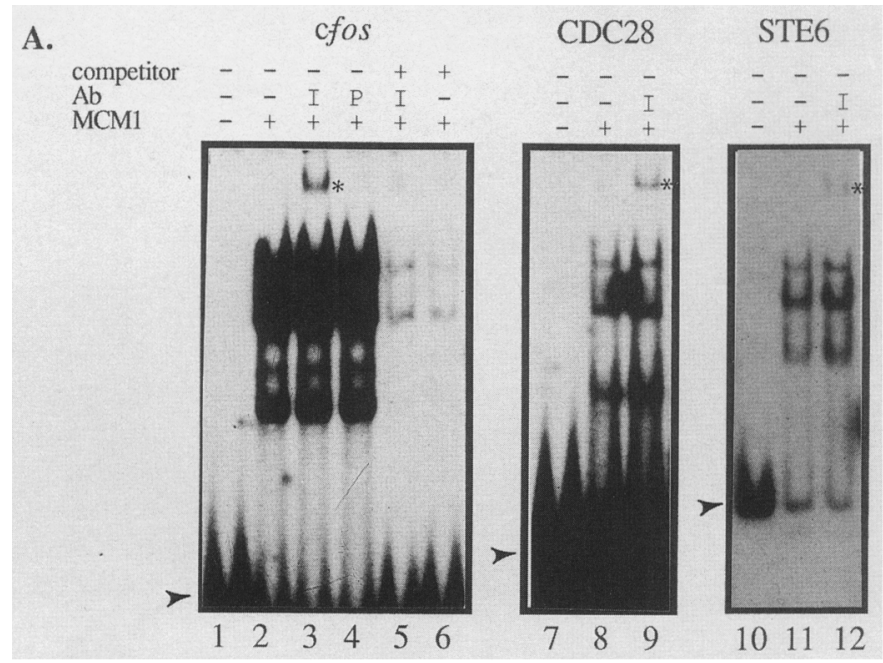

B.

\begin{tabular}{|ll|}
\hline MCE & CCTAATTAGG \\
STE2 & CCTAATTGGG \\
STE6 & CCTAATAGGG \\
CDC28 & CCTAATAAGG \\
C-fos & CCTAATATGG \\
\hline
\end{tabular}

Figure 7. Binding of the MCM1 protein to the human C-fos SRE, the yeast CDC28 MCE, and the yeast STE6 MCE. $(A)$ Oligonucleotides containing SRE or MCE sequences from c-fos, CDC28, and STE6 were used as binding substrates. Ten femtomoles of the binding sequence was used as cold competitor DNA. Arrows indicate unbound labeled substrate and asterisks indicate the slower migrating band due to the formation of antibody-MCM1-DNA complex. $|B|$ Comparison of the MCE-like sequences of the different substrates.

fect on its expression in $\alpha$ cells. This expression was dependent on a 336-bp HindIII fragment upstream of the STE2 gene. This HindIII fragment contains the MCM1binding site flanked on either side by $\alpha 2$-binding sites, and thus is similar in organization to the operator site of STE6. The STE2-lacZ fusion gene which lacks the HindIII fragment $(\mathrm{CDH})$ shows low activity in both a and $\alpha$ cells and does not respond to changes in the level of MCM1.

In contrast to the STE2 URS, which acts as a cell-typespecific UAS, DSE ${ }_{14}$ acts as a cell-type-nonspecific UAS, a result similar to that reported by Jarvis et al. (1988). Only a modest stimulation in the UAS activity of $\mathrm{DSE}_{14}$ was observed with increased levels of MCMl (Fig. 8B), while carboxy-terminal disruptions of MCM1 result in a drastic decrease in activation by this sequence (R. Elble, unpubl.). The c-fos SRE exhibited no detectable UAS activity in wild-type strains of either mating type. However, overproduction of MCM1 stimulated expression at least sevenfold. Like DSE ${ }_{14}$, this element did not show cell-type specificity.

We used a competition assay (see Experimential procedures) to measure the relative binding affinities of DSE $_{14}$, STE2-o, MFod-o, and the c-fos SRE for MCM1 $(1-188)$. The amount of cold competitor necessary to reduce by half the amount of bound c-fos SRE was determined using a gel-retardation assay. The relative binding affinities of MCM1 (1-188) for these sites are presented in Table 1. The affinity of MCM1 for these elements in decreasing order is: DSE $_{14}>$ STE2-o $>$ MFad-o $>$ c-fos SRE. The relative UAS activity for these different sequences is STE2 $>D_{D S E}>c$-fos SRE. The higher affinity of MCM1 (1-188) for DSE $_{14}$ compared with the c-fos SRE is consistent with the higher UAS activity observed for $\mathrm{DSE}_{14}$ in vivo. However, the STE2-o-binding affinity cannot be compared directly with the UAS ac- tivity of STE2 because the HindIII fragment used in this construction is known to contain another MCM1-independent UAS (Smith 1986). We expected that the MCM1-dependent enhancement of the UAS activity should reflect the binding affinity: Sequences that have the highest affinity should be the least enhanced by MCM1 overproduction if the concentration of MCM1 is saturating for the high-affinity sites. This was, in fact, the case (Table 1).

These studies demonstrate that MCM1 has the property crucial to transcription factors that regulate a large number of genes. It can exert different effects on its target sites depending on its affinity to the target site and the factors that modulate its binding to these sites.

\section{Discussion}

Role of MCM1 in the expression of mating-type-specific genes

We have presented evidence that confirms the role of MCM1 as a transcriptional regulator by showing that MCMI binds to the upstream-regulatory sites of a- and $\alpha$-specific genes. Moreover, MCM1 appears to bind cooperatively with $\alpha 1$ to the UASs of $M F \alpha 1$ and probably other $\alpha$-specific genes as well. In addition, we have shown that oligonucleotides containing the MCM1binding site exhibit UAS activity in vivo, and that this activity is responsive to the level of MCM1.

The DNA-binding specificity of the MCM1 protein suggests that it is related to GRM and PRTF, two previously identified DNA-binding activities found in yeast extracts. The mutant phenotypes of $m \mathrm{~cm} 1-1$ suggest that MCM1 plays an important role in the regulation of mating-type-specific genes in $\alpha$ cells by working in concert with the $\alpha 1$ protein. 
A.

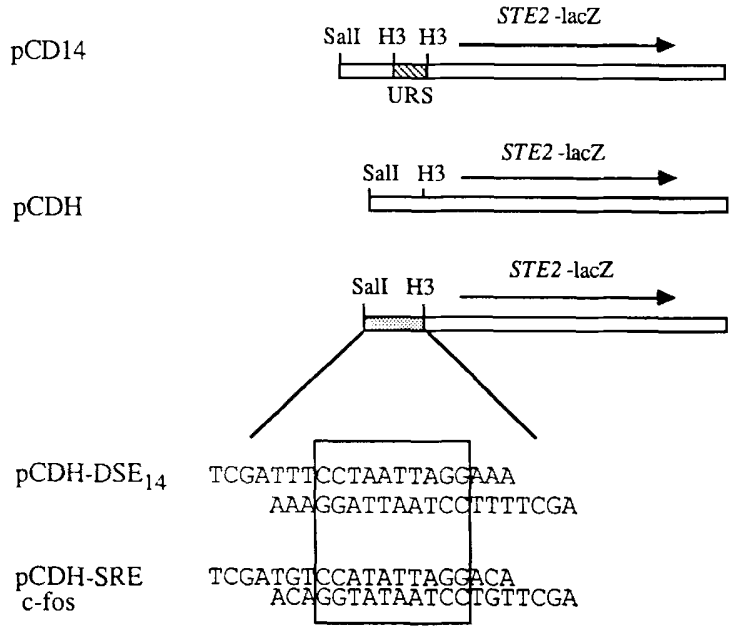

B.

\begin{tabular}{lcrcc}
$\begin{array}{l}\text { Plasmids } \\
\text { Strains }\end{array}$ & pCDH & $\mathrm{pCD} 14$ & $\mathrm{pCDH}^{-D S E_{14}}$ & $\begin{array}{c}\text { pCDH-SRE } \\
\mathrm{c}-\text { fos }\end{array}$ \\
\hline$a$ & 22 & 1791 & 140 & 11 \\
$\alpha$ & 28 & 41 & 155 & 21 \\
$\alpha[2 \mu M C M I]$ & 22 & 28 & 263 & 140 \\
$a[2 \mu M C M I]$ & -- & 3404 & - & 106 \\
\hline
\end{tabular}

Figure 8. Effect of elevated levels of MCMI on the UAS activity of c-fos SRE, STE2 UAS, and MCE in yeast. $|A|$ Construction of plasmids to test the effect of different upstream sequences as UASs to the STE2-lacZ reporter gene. Plasmids contain LEU2 CEN5 ARS1, except for pCD14, which contains LEU2 CEN3 ARS1. (B) UAS activity of different sequences measured by $\beta$-galactosidase activity. a and $\alpha$ strains are congenic strains. a strain $=1828$ lade2 his $3 \Delta 200$ trp1-1 ura3-52 leu2-3,112), a strain = 1829 (lys2 his34200 trp1-1 ura3-52 leu2$3,-112)$. A $2 \mu$ plasmid containing MCM1 and URA3 was transformed into these strains to give an increased intracellular concentration of MCM1.

The mcm1-1 mutation causes reduced transcription of $\alpha$-specific genes (Passmore et al. 1988) and this mutation can be suppressed partially by the overproduction of the $\alpha 1$ protein (C. Christ, unpubl.). We have shown that MCMl is able to bind to the UASs of $\alpha$-specific genes without the help of the $\alpha 1$ protein. Although MCM1 expression is cell-type independent, the $\alpha$-specific genes are not expressed in a-cells. We presume that the intracellular levels of MCM1 are not high enough to allow efficient binding to the $\alpha$-specific UASs in the absence of its cofactor $\alpha 1$. Our previous results, which showed that overproduction of MCMI can suppress partially the mating defect of a mata1 mutation (Passmore et al. 1988), are consistent with this interpretation. These properties suggest that MCM1 may encode PRTF (Bender and Sprague 1987; Jarvis et al. 1988).

MCM1 seems to play only a limited role in the expression of a-specific genes in a cells. This is evident from the twofold reduced expression of STE2 in the mcm1-1 mutant (Passmore et al. 1988) and from the weak UAS activity supplied by the MCM1-binding site within the $\alpha 2$ operator upstream of STE6 (Keleher et al. 1988). Consistent with these observations, the in vitrobinding affinity of MCMI for the MCE upstream of aspecific genes is very similar to its affinity for the MCEs of $\alpha$-specific genes, which require the presence of $\alpha 1$ for efficient expression. The involvement of MCM1 in repression of a-specific genes is suggested by genetic evidence. Deletion mutations removing the carboxy-terminal region of $M C M 1$, which encodes glutamine-rich tracts, result in the derepression of a-specific genes in $\alpha$ cells (R. Elble, unpubl.). Substitution mutations of the MCM1-binding site within an $\alpha 2$ operator fail to repress a-specific transcription in $\alpha$-cells (Keleher et al. 1988). The derepression of a-specific genes in certain $\mathrm{mcm} 1$ mutants and the DNA-binding specificity of MCM1, suggest that MCM1 may encode GRM, the corepressor with $\alpha 2$ of a-specific genes.

These genetic and biochemical properties of MCM1 are summarized in a model (Fig. 9) modified from Keleher et al. (1988) and Sauer et al. (1988). In this model, MCM1(GRM/PRTF) plays an important role in the regulation of mating-type-specific genes in $\alpha$ cells by working in concert with the $\alpha 1$ and $\alpha 2$ proteins. The $\alpha 1$ protein is required in vivo for transcription of $\alpha$-specific genes and it functions by enhancing MCM1(PRTF) binding to the a-specific UASs interacting specifically with ATTAGG on both strands of the MCE. Once bound, MCM1 can present its acidic domain to the transcription machinery and activate transcription. Moreover, MCM1(GRM) functions with $\alpha 2$ as a repressor of a-specific genes in $\alpha$ cells. GRM(MCM1) and $\alpha 2$ bind cooperatively (Keleher et al. 1988; Sauer et al. 1988), suggesting that the proteins interact. We propose that $\alpha 2$ interacts with MCMI such that it masks the acidic patch, rendering MCM1 incapable of activating transcription. In addition, this complex forms an effective block to transcription mediated by other UASs by some as yet unknown means (Keleher et al. 1988).

MCM1 is an essential gene, and therefore must function beyond the capacity of a regulator of mating-typespecific gene expression. MCM1 may act as a more global transcriptional regulator that is required for the expression of a number of essential genes, one being the CDC28 gene. We have shown that MCM1 can interact with a DNA element located 142 bp upstream of the $C D C 28$ transcription start site. CDC28 encodes a protein kinase involved in the regulation of the progression of the yeast cell cycle from $G_{1}$ to $S$, perhaps being required for the initiation of DNA synthesis (Hereford and Hartwell 1974).

\section{The binding of MCM1 to DNA}

We have shown that MCM1 (1-188) binds to a number of sequences related to the consensus dyad symmetry element CCTAATTAGG. The regulatory regions of both a- and $\alpha$-specific genes contain MCEs that are 
Table 1. Specificity of MCE binding to MCM1 in vitro and UASs function in vivo.

\begin{tabular}{|c|c|c|c|c|}
\hline & name & sequence & $\begin{array}{l}\text { relative } \\
\text { affinity }\end{array}$ & $\begin{array}{l}\text { overproduction } \\
\text { enhancement }\end{array}$ \\
\hline \multirow{8}{*}{$\begin{array}{l}\text { binding } \\
\text { sites }\end{array}$} & $\mathrm{DSE}_{14}$ & TTCCTAATTAGGAA & 1.0 & 1.7 \\
\hline & $M F \propto p-0$ & TTCCTAATTAGGCC & - & - \\
\hline & MFad-0 & TTCCTAATAAGTCC & 0.6 & - \\
\hline & STE2-O & TTCCTAATTGGGGT & 0.7 & 1.9 \\
\hline & STE6-O & TACCTAATAGGGCC & - & - \\
\hline & $c-f o s$ & GTCCTAATATGGAC & 0.4 & 8 \\
\hline & $\operatorname{CDC} 28$ & GCCCTAATAAGGCC & - & - \\
\hline & ССТAAT & TTCСТАATTTCCTA & - & - \\
\hline \multirow{6}{*}{$\begin{array}{l}\text { mutant } \\
\text { sites }\end{array}$} & consensus & \multicolumn{3}{|l|}{ ttCCTAAT ${ }_{\mathrm{t}}^{\mathrm{a}} \mathrm{nGGnn}$} \\
\hline & +2 & \multicolumn{3}{|l|}{ TTCCTAAATTTAGGAA } \\
\hline & -2 & \multicolumn{3}{|l|}{ TTCCTATAGGAATT } \\
\hline & T3A & \multicolumn{3}{|l|}{ TTCCAAATTTGGAA } \\
\hline & $\mathrm{A} 4 \mathrm{~T}$ & \multicolumn{3}{|l|}{ TTCCTTATAAGGAA } \\
\hline & A5 T & \multicolumn{3}{|l|}{ TTCСTATATAGGAA } \\
\hline
\end{tabular}

(Top) Various sequences that bind MCM1. Boldface characters indicate the highly conserved CCTAAT motif in the "left half" of the dyad symmetry element and italics indicates the conserved GG in the "right half." Relative affinity of the sequence for MCMl was determined by a quantitative competition assay as described in Experimental procedures. Overproduction enhancement is the increase in transcription that results when MCM1 is present on a high-copy plasmid and is derived from Fig. 7. (Bottom) Mutant sites that do not bind MCM1. Boldface indicates the position of mismatches to the 10-bp DSE CCTAATTAGG.

bound by MCM1 $(1-188)$ in vitro. Our binding data are summarized in Table 1. We have constructed a series of symmetric double mutations within the MCE that change the sequence of both 'half-sites' in the internal AT-rich region. None of the mutant binding sites was an efficient competitor, which indicates that the sequence of the innermost six positions of the MCE is important for binding. A conserved sequence, CCTAAT, is found in all of the substrates we have examined that are recognized by MCM1 (1-188). Deviations from DSE $_{10}$ occurring at every position other than CCTAAT are tolerated. One binding substrate, the CCTAATT polymer, which contains only one of the half-sites, was of particular interest: It served as a competitor for the binding of MCM1 to the symmetric MCE. Nicking interference experiments indicate that $\mathrm{MCMl}$ interacts with each ATTAGG of the MCE on both strands. Furthermore, methylation of $G_{9}$ or $G_{10}$ on either strand abolishes binding of MCM1. Together these results suggest that MCM1 binds as a dimer to symmetric sites within the MCE.

The relative affinities of MCM1 $(1-188)$ for some of the binding sites have been determined. We found that those sequences that were the best binding substrates in vitro were enhanced the least by increasing the levels of MCM1 in vivo. This inverse correlation suggests that the intracellular concentration of MCM1 is such that binding sites of different affinities can use MCM1 to drive transcription at different levels. This is a property expected of a transcription factor that regulates multiple genes.

Multiple bands corresponding to MCM1-DNA complexes are seen in gel-retardation assays, even when oligonucleotides containing a single 10-bp-binding site were used as substrate. We suspect that the multiple bands arise from homo- and heterodimers of MCM1 $(1-188)$ and its proteolytic fragment binding to a common substrate. Two lines of evidence suggest that this is the cause of the multiple bands: (1) MCM1 purified from a SDS-polyacrylamide gel and then renatured gives only one shifted complex and (2) the various shifted complexes have the same DNase I footprints.

\section{Cooperative binding of MCM1 with $\alpha 1$}

The binding of MCMl to $\alpha$-specific UASs can be potentiated by the regulatory protein MAT $\alpha 1$. The $\alpha 1$ protein is believed to act by binding to a conserved sequence motif found in $\alpha$-specific UASs. This motif is located immediately adjacent to the MCEs of the $\alpha$-specific genes. We have shown that addition of $\alpha 1$ enhances the binding of MCM1 to MF 1 -UAS2. In addition, the region protected from DNase I digestion is extended in the presence of $\alpha 1$ to include the conserved motif. These results suggest that MCM1 and $\alpha 1$ bind cooperatively to the UASs of $\alpha$-specific genes. It is possible that the $\alpha 1$ protein enhances the formation of the MCM1-DNA complex solely by interacting with $M C M 1$, rather than by binding directly to the $\alpha$-specific UAS. Our inability to detect $\alpha 1$ enhancement of MCM1 binding to a-specific genes makes this interpretation unlikely. We have been unable to detect any change in the mobility of the MCM1-DNA complex in the presence of the $\alpha 1$ protein. Perhaps the $\alpha 1 / \mathrm{MCM} 1-\mathrm{DNA}$ complex was not stable under the conditions used in the gel-retardation assay; alternatively, it is possible that the mobility of an $\alpha 1 /$ MCM1-DNA complex is indistinguishable from that of an MCM1-DNA complex.

\section{Relationship to other transcription factors}

MCM1 is a member of a family of related proteins that may all function as transcription factors. MCMl bears 
Passmore et al.

$\alpha$-specific UAS

on

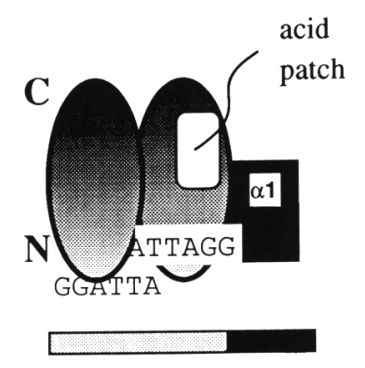

MCE $\alpha 1$ site a-specific URS

off

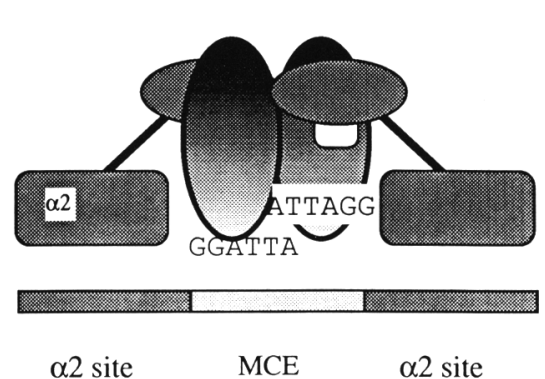

Figure 9. Summary of the properties and function of MCM1 in the regulation of mating-type-specific genes in $\alpha$ cells based on a model modified from Keleher et al. (1988) and Sauer et al. (1988).

striking homology to the yeast protein ARG80, a transcriptional or post-transcriptional (Messenguy and Dubois 1983) regulator of the arginine metabolic pathway. Within a region of 79 amino acids there is $70 \%$ identity between these two proteins (Passmore et al. 1988). Both MCM1 and ARG80 may function as components of multisubunit complexes. $\alpha 1$ enhances the binding of MCM1 to $\alpha$-specific UASs and both are needed for expression of $\alpha$-specific genes, whereas MCM1 and $\alpha 2$ interact to repress the expression of $\mathbf{a}^{-}$ specific genes. Genetic evidence suggests that ARG80, $A R G 81$, and $A R G 82$ interact to promote the expression of catabolic genes of the arginine pathway and to repress arginine anabolic genes (Bechet et al. 1970). Although we believe that MCM1 encodes GRM and PRTF based on their DNA-binding specificities and their postulated role in the control of mating-type-specific expression, we cannot rule out the possibility that they are members of a family of related transcription factors. There are precedents for distinct transcription factors that have similar DNA-binding specificities and immuno-crossreactivities (Santoro et al. 1988).

A sequence motif used by higher cells to control genes responsive to growth factors resembles the MCM1binding site. The sequence element SRE is acted on by the transcription factor SRF. We have shown that the MCM1 protein will bind to the SRE. Furthermore, the human c-fos SRE can act as a UAS in the expression of genes in yeast when the MCM1 protein is present at high levels in the cell. A comparison of the protein sequences of MCMI and human SRF shows that they are highly homologous to each other in the DNA-binding/ dimerization domain, a domain that also is conserved between the MCM1 and ARG80 proteins (Norman et al. 1988; Passmore et al. 1988). Thus, the transcription factors MCM1 and SRF, as well as their DNA recognition sequences, have been conserved over large evolutionary distances.

\section{Possible role in DNA replication}

MCM1 is a versatile transcription factor that can act as a transcriptional activator when presented with $\alpha 1$ and a transcriptional repressor when presented with $\alpha 2$. It is possible that if presented with the appropriate factor|s|, it may serve yet another important role in the cell - to regulate DNA replication initiation either as a transcriptional regulator of genes involved in DNA replication or as a DNA replication initiator. The $m c m 1-1 \mathrm{mu}$ tation was isolated originally as a mutation that affected the function of specific ARSs on minichromosomes. Inspection of nucleotide sequences of ARSs reveals that there are multiple MCE-like elements in certain ARSs (V. Chang, unpubl.). Many examples of site-specific DNA-binding proteins playing dual roles in transcriptional activation and replication initiation in eukaryotes have been described (Dean et al. 1987; Jones et al. 1987; Mecas and Studgen 1987; Pruijn et al. 1987; Stenlund et al. 1987; O'Neill and Kelly 1988). A recent report by Santoro et al. (1988) convincingly showed that a family of CCAAT-box binding proteins serves both as promoter-selective transcription activators and as initiation factors for DNA replication in mammalian in vitro systems. It is tempting to speculate that in yeast, the transcription of mating-type-specific genes and the initiation of DNA replication may be regulated by MCM1 via similar control elements. This control mechanism may be conserved in evolutionarily diverse organisms to allow the transcription of growth-related genes and the initiation of DNA replication to coordinately respond to the same growth stimuli.

\section{Experimental procedures}

Overproduction and purification of MCM1 protein

The plasmid pETMCM1 (1-188) was constructed to overexpress a phage T7 $\phi-10-M C M 1$ fusion protein. A DNA fragment, 
which extends from a BamHI linker 14 bp upstream of the start of translation to the EcoRI site within the coding sequence of the $M C M 1$ gene, was placed into the expression plasmid pET3b, which had been cut with these same two enzymes (Rosenberg et al. 1987). pETMCM1 (1-188) was transformed into the strain BL21(DE3), which carries an integrated, inducible copy of the phage T7 RNA polymerase. This strain also contains a plasmid (pLysE) that constitutively expresses a low level of the phage T7 lysozyme, which inhibits the basal T7 RNA polymerase activity. The expression of the MCM1 fusion protein was induced by the addition of isopropyl- $\beta$ - $D$-thiogalactopyranoside to $1 \mathrm{mM}$ to a rapidly growing culture at $\mathrm{OD}_{660}=0.4$. After $2 \mathrm{hr}$, the culture was harvested, washed, and then lysed by repeated freezethaw cycles in buffer LB150 containing 3\% streptomycin sulfate. LB150 is lysis buffer (LB) containing $150 \mathrm{mM} \mathrm{NaCl}$. LB buffer is $50 \mathrm{~mm}$ Tris- $\mathrm{HCl}\left(\mathrm{pH}\right.$ 7.9), $10 \mathrm{mM} \mathrm{BME}, 1 \mathrm{mM} \mathrm{MgCl}_{2}$, and $0.1 \mathrm{mM}$ EDTA. This lysate was cleared by a $1-\mathrm{hr} 30,000 \mathrm{~g}$ spin at $4^{\circ} \mathrm{C}$ and then loaded onto a BioRex 70 column equilibrated with LB150. The MCM1 protein was eluted from this column with a linear $\mathrm{NaCl}$ gradient in $\mathrm{LB}$ and eluted at $\sim 580$ $\mathrm{mM} \mathrm{NaCl}$. The MCMl protein was assayed during the purification both for its DNA-binding activity, and by immunoblot analysis of the various fractions. The peaks of binding activity and immuno-cross-reactive material were coincident. The MCM1 protein obtained from the elution peak is $\sim 30 \%$ MCM1, as judged by Coomassie brilliant blue staining of the peak fractions when separated by SDS-PAGE.

\section{Antisera preparation and immunological techniques}

The plasmid pURMCM1 was constructed to overexpress a LacZ-MCM1 fusion protein. The 575-bp BamHI-EcoRI fragment from BH-14 (Passmore et al. 1988) was inserted into the plasmid pUR278 (Rüther and Müller-Hill 1983), creating a translational fusion of the $1 a c Z$ and MCM1 genes. This gene fusion encodes a 1219-amino-acid protein containing the amino-terminal 188 amino acids of the MCM1 protein. An E. coli strain bearing this plasmid was induced to express the LacZ-MCM1 fusion protein by the addition of IPTG. Total protein from this strain was fractionated by SDS-PAGE, as described by Laemmli (1970), using an $8 \%$ resolving gel. The LacZ-MCM1 protein was electroeluted from the gel, mixed with Freund's complete adjuvant, and used to immunize New Zealand White rabbits. The rabbits were boosted three times with antigen in Freund's incomplete adjuvant and the immune sera was harvested, 9 weeks after the initial immunization.

The immunoblots were performed as follows: proteins were transferred from SDS-PAGE onto nitrocellulose and probed using rabbit anti-MCM1 antisera, essentially as described by Towbin (1979), except that $5 \%$ nonfat powdered milk was used as a blocking agent. Bound antibody was detected using goat anti-rabbit IgG conjugated to alkaline phosphatase (Bio-Rad), which was visualized as described by the supplier.

\section{Footprint reactions}

The DNAs used in the footprinting experiments of the regulatory region of $M F \alpha 1$ were the plasmid $\mathrm{pKSMF} \alpha 1$ and the oligonucleotide MF $\alpha 1 \mathrm{p} 60$. pKSMF $\alpha 1$ was constructed by inserting the $S$ spI-Xholl DNA fragment containing the $M F \alpha 1$ regulatory elements from the plasmid pHK2 (provided by I. Herskowitz) into the polylinker of the plasmid BluescriptKS $|+|$ which had been cut with SmaI and BamHI. pKSMF $\alpha 1$ was $3^{\prime}$-end-labeled by first cutting with the enzyme HindIII, then filling in the ends with T4 DNA polymerase. This DNA was then recut with the enzyme BamHI and the fragment was isolated from a $6 \%$ polyacrylamide gel. MF $\alpha 1$ p60 was 3'-end-labeled on the coding strand using the Klenow form of DNA polymerase I and radioactive dATP, and the noncoding strand was labeled similarly using radioactive dCTP. The DNase I cleavage was carried out in two steps. First, labeled DNA and MCMI protein were mixed and allowed to bind at room temperature for $10 \mathrm{~min}$ in BB [150 mM NaCl, $20 \mathrm{~mm}$ Tris- $\mathrm{HCl}(\mathrm{pH} 8.0), 1 \mathrm{mM} \mathrm{MgCl}_{2}, 5$ $\mathrm{mM} \mathrm{CaCl}_{2}, 0.1 \mathrm{~mm}$ EDTA, $10 \%$ glycerol, $0.1 \mu \mathrm{g} / \mu \mathrm{l} \mathrm{BSA}, 1 \mathrm{ng} / \mu \mathrm{l}$ poly[d(I-C)]. Then poly[d(I-C)] was added to $50 \mathrm{ng} / \mu \mathrm{l}(20-\mu \mathrm{l}$ reaction) followed by addition of DNase I. Except as noted above, solution cleavage conditions and further processing were essentially as described by Wiederrecht et al. (1987). The DNase I digestion patterns of the different forms seen in the gel-retardation assay were examined by first carrying out the footprinting reaction as described above using end-labeled MF $\alpha$ lp 60 followed by a preparative retardation gel. The bands of interest were excised, diffusion-eluted into TE, and concentrated by butanol extraction. The pKSMF $\alpha 1$ cleavage products were then separated on an $8 \%$ sequencing gel using sequencing reactions for size standards. MF $\alpha 1 \mathrm{p} 60$ cleavage products were separated on an $13 \%$ sequencing gel.

\section{Nicking and DMS interference assays}

To identify the strand and sequence positions important for MCM1 binding, DNase I nicking was used as the basis for a binding-interference assay. DNA from the promoter of $M F \alpha 1$ was nicked using DNase I, this collection of nicked DNA was then allowed to bind under conditions of protein excess and the bound and nonbound forms were fractionated using the gel-retardation system, followed by separation of the denatured DNA on a sequencing gel. The oligonucleotide $M F \alpha 1 \mathrm{p} 60$ was used for all the nicking interference assays; this DNA was 3'-end-labeled using the Klenow fragment of DNA polymerase I. The DNase I digestion conditions are essentially as described above (see Footprint reactions). To identify base positions that are essential for binding, all of these assays were carried out in the presence of excess protein, such that greater than $95 \%$ of the input DNA was shifted in the absence of DNase I treatment. The bound and nonbound classes were fractionated using the gel system described for the PAGE-retardation experiments. The bound and nonbound classes of nicked DNA were identified by autoradiography; a gel slice containing these DNAs was excised and crushed and the DNA was eluted into TE by an overnight incubation at $4^{\circ} \mathrm{C}$. The eluted DNA was concentrated by extraction with $N$-butanol, dried, denatured by heating in formamide loading dye, and applied directly to a sequencing gel. DNA was methylated partially with dimethylsulfate, and precipitated from ethanol several times. The methylated DNA was used for an interference assay as described above. After isolation, the bound and nonbound forms were cleaved using the $\mathrm{G}$ greater than A method, as described by Siebenlist and Gilbert (1980).

\section{PAGE retardation experiments}

Unless otherwise noted, all substrates for gel-retardation experiments were labeled by replacement synthesis using T4 DNA polymerase, essentially as described by O'Farrell (1981). The labeled DNA was purified by PAGE before use. Oligonucleotides were labeled either by T4 kinase or by filling in ends with the Klenow fragment of polymerase. Approximately $2 \mathrm{ng}$ lexcept as noted in the figures) of the MCM1 protein was mixed in $20 \mu 1$ $\mathrm{BB}$ followed by addition of probe $(\sim 1 \mathrm{fM})$. The binding was allowed to occur at room temperature for $10 \mathrm{~min}$. The DNA- 
protein complexes were resolved on a $15 \mathrm{~cm}, 6 \%$ polyacrylamide gel $(40: 1$, acrylamide/bis) buffered with TB [50 mM Tris-borate (pH 8.7), $1.0 \mathrm{~mm}$ EDTA] at $150 \mathrm{~V}$ for $1-4 \mathrm{hr}$ as appropriate for the DNA fragment of interest. The free DNA and DNA-protein complexes were then visualized by autoradiography.

\section{Quantitative competition assays}

Polymers of the binding site mutations were used as competitors. Approximately $1 \mathrm{fm}$ of probe was present in each reaction, and the competitor was added to the reaction prior to the addition of the probe. Quantitative competition assays were performed using the c-fos MCE as the probe in a gel-retardation assay under conditions that $\sim 30 \%$ of the probe formed DNAprotein complexes. Various amounts of cold competitor DNAs were added before addition of MCM1-188 protein. Autoradiograms were scanned using a BioRad model 620 video densitometer. The amount of cold competitor necessary to reduce the amount of shifted probe by half $\left(\mathrm{S}^{1} / 2\right)$ was calculated. Relative affinities were calculated as the ratio of the $S^{1 / 2}$ of $D_{S E_{14}}$ to the $\mathrm{S} 1 / 2$ of the particular oligonucleotide.

\section{Oligonucleotides}

Oligonucleotides were synthesized by the Cornell oligonucleutide synthesis facility, except for STE6-o which was a gift from C. Keleher. Their sequences are shown below or in the appropriate figures.

\begin{tabular}{|c|c|}
\hline Name & Sequence \\
\hline \multirow[t]{2}{*}{ MFad-o } & CCGGGTTCCTAATTAGTCCA \\
\hline & CAAGGATTAATCAGGTACGT \\
\hline \multirow[t]{2}{*}{ STE2-0 } & CCGGGTTCCTAATTGGGTA \\
\hline & CAAGGATTAACCCATAGCT \\
\hline \multirow[t]{2}{*}{ STE6-0 } & TCGACTAATTACCTAATAGGGAAATTTC \\
\hline & GATTAATGGATTATCCCTTTAAAGAGCT \\
\hline \multirow[t]{2}{*}{ DSE $_{14}$} & AATTCTTCCTAATTAGGAAG \\
\hline & GAAGGATTAATCCTTCTTAA \\
\hline \multirow[t]{2}{*}{$\mathrm{CDC} 28$} & CCGCCCTAATAAGGCCAT \\
\hline & CGGGATTATTCCGGTATATACATAGG \\
\hline \multirow[t]{4}{*}{ MF $\alpha 1$ p 60} & GGGTCGACGGAACACCTTCCTAATTAGGCCATCAACGACAGTAAATT \\
\hline & AGCTGCCTTGTGGAAGGATTAATCCGGTAGTTGCTGTCATTTAA \\
\hline & CCCAAGCTTGGG \\
\hline & GGGTTCGAACCCTTT \\
\hline
\end{tabular}

\section{$\beta$-Galactosidase activity assays}

$\beta$-Galactosidase activity assays were carried out as described by Guarente (1983), except that a washing step was introduced to remove the red color resulting from the ade2 mutation in the a strain. Cells were permeabilized in chloroform/SDS, pelleted by centrifugation, and resuspended in Z-buffer (Guarente 1983) containing chloroform/SDS and $\alpha$-nitrophenyl- $\beta$-D-galactoside. Units of $\beta$-galactosidase activity were calculated as: $\left(\mathrm{OD}_{420} \times 1000\right) /(t \times \mathrm{m})$; where $t$ is reaction time in minutes and $\mathrm{m}$ is milligrams of cell protein. Protein content was determined using the Bradford protein assay after breaking the cells with glass beads.

\section{Acknowledgments}

We thank Beth Grayhack for providing us the $\alpha 1$ protein. We are especially indebted to Elizabeth Keller and John T. Lis for their constructive comments and critical reading of the manuscript. We thank Olga Pereisic for invaluable discussions that led to development of the nicking interference assay and Joe Henderson for construction of pURMCMl. This work was supported by grants from the National Institutes of Health and the
Cornell University Biotechnology Program which is sponsored by the New York State Science and Technology Foundation, a consortium of industries, the U.S. Army Research Office, and the National Science Foundation.

\section{References}

Baum, P., C. Furlong, and B. Byers. 1986. Yeast gene required for spindle pole body duplication: Homology of its product with $\mathrm{Ca}^{2+}$-binding proteins. Proc. Natl. Acad. Sci. 83: $5512-5516$.

Bender, A. and G.F. Sprague, Jr. 1987. MAT $\alpha 1$ protein, a yeast transcription activator, binds synergistically with a second protein to a set of cell-type-specific genes. Cell 50: 681-691.

Bechet, J., M. Grenson, and J.M. Wiame. 1970. Mutations affecting the repressibility of arginine biosynthetic enzymes in Saccharomyces cerevisiae. Eur. J. Biochem. 12: 31-39.

Brewer, B.J. and W.L. Fangman. 1987. The localization of replication origins on ARS plasmids in S. cerevisiae. Cell 51: 463-471.

Dean, F.B., J.A. Borowiec, Y. Ishimi, S. Deb, P. Tegtmeyer, and J. Hurwitz. 1987. Simian virus 40 large tumor antigen requires three core replication origin domains for DNA replication in vitro. Proc. Natl. Acad. Sci. 84: 8267-8271.

Dubois, E., J. Bercy, and F. Messenguy. 1987. Characterization of two genes, $A R G R I$ and $A R G R I I I$, required for specific regulation of the arginine metabolism in yeast. Mol. Gen. Genet. 207: 142-148.

Earnshaw, W.C., K.F. Sullivan, P.S. Machlin, C.A. Cooke, D.A. Kaiser, T.D. Pollard, N.F. Rithfield, and D.W. Cleveland. 1987. Molecular cloning of cDNA for CENP-B, the major human centromere autoantigen. J. Cell Biol. 104: 817-829.

Fields, S. and I. Herskowitz. 1985. The yeast STE12 product is required for expression of two sets of cell-type-specific genes. Cell 42: 923-930.

Gibson, S., R. Surosky, P. Sinha, G. Maine, and B.-K. Tye. 1987. Complexity of the enzyme system for the initiation of DNA replication in yeast. UCLA Symp. Mol. Cell Biol., new series 47: 341-354.

Guarente, L. 1983. Yeast promoters and lacZ fusions designed to study expression of cloned genes in yeast. Methods Enzymol. 101: $181-187$.

Hartig, A., J. Holly, G. Saari, and V.L. McKay. 1986. Multiple regulation of STE2, a mating-type-specific gene of Saccharomyces cerevisiae. Mol. Cell. Biol. 6: 2106-2114.

Hayes, T.E., P. Sengupta, and B.H. Cochran. 1988. The human c-fos serum response factor and the yeast factors GRM/ PRTF have related DNA-binding specificities. Genes Dev. 2: $1713-1722$

Hereford, L.M. and L.H. Hartwell. 1974. Sequential gene function in the initiation of Saccharomyces cerevisiae DNA synthesis. J. Mol. Biol. 84: 445-461.

Hope, I. and K. Struhl. 1986. Functional dissection of a eukaryotic transcriptional activator protein, GCN4 of yeast. Cell 46: $885-894$.

Huberman, J.A., L.D. Spotila, K.A. Nawotka, S.M. El-Assouli, and L.R. Davis. 1987. The in vivo replication origin of the yeast $2 \mu$ plasmid. Cell 51: $473-481$.

Inokuchi, K., A. Nakayama, and F. Hishinuma. 1987. Identification of sequence elements that confer cell-type-specific control of MFo1 expression in Saccharomyces cerevisiae. Mol. Cell. Biol. 7: 3185-3193.

Jarvis, E., D.C. Hagen, and G.F. Sprague, Jr. 1988. Identification of DNA segment that is necessary and sufficient for $\alpha$-specific and a-specific genes: Implications for regulation of $\alpha$ specific and a-specific genes. Mol. Cell. Biol. 8: 309-320. 
Jones, K.A., J.T. Kadonaga, P.J. Rosenfield, T.J. Kelly, and R. Tijan. 1987. A cellular DNA-binding protein that activates eukaryotic transcription and DNA replication. Cell 48: 7989.

Keegan, L., G. Gill, and M. Ptashne. 1986. Separation of DNA binding from the transcription-activating function of a eukaryotic regulatory protein. Science 231: 699-704.

Keleher, C.A., C. Goutte, and A.D. Johnson. 1988. The yeast cell-type-specific repressor $\alpha 2$ acts cooperatively with a non-cell-type-specific protein. Cell 53: 927-936.

Laemmli, U.K. 1970. Cleavage of structural proteins during the assembly of the head of bacteriophage T4. Nature 277: 680685.

Lorincz, A. and S. Reed. 1984. Primary structure homology between the product of yeast cell division control gene $c d c 28$ and vertebrate oncogenes. Nature 307: 183-185.

Maine, G.T., P. Sinha, and B.-K. Tye. 1984. Mutants of S. cerevisiae defective in the maintenance of minichromosomes. Genetics 106: 365-385.

Mecas, J. and B. Studgen. 1987. Replication of plasmids derived from bovine papilloma virus type I and Epstein-Barr virus in cells in culture. Annu. Rev. Cell Biol. 3: 87-108.

Messenguy, F. and E. Dubois. 1983. Participation of transcriptional and post-transcriptional regulatory mechanisms in the control of arginine metabolism in yeast. Mol. Gen. Genet. 189: 148-156.

Norman, C., M. Runswick, R. Pollock, and R. Treisman. 1988. Isolation and properties of cDNA clones encoding SRF, a transcription factor that binds to the c-fos serum response element. Cell 55: 989-1003.

O'Farrell, P. 1981. Replacement synthesis method for labeling DNA fragments. Bethesda Research Labs FOCUS 3: 1-3.

O'Neill, E.A. and T.J. Kelly. 1988. Purification and characterization of nuclear factor III /origin recognition protein $\mathrm{C}$, a sequence-specific DNA binding protein required for efficient initiation of adenovirus DNA replication. I. Biol. Chem. 263: 931-937.

Passmore, S., G.T. Maine, R. Elble, C. Christ, and B.-K. Tye. 1988. Saccharomyces cerevisiae protein involved in plasmid maintenance is necessary for mating of MAT $\alpha$ cells. J. Mol. Biol. 204: 593-606.

Pruijn, G.J.M., W. van Driel, R.T. van Miltenburg, and P.C. van der Vliet. 1987. Promoter and enhancer elements containing a conserved sequence motif are recognized by nuclear factor III, a protein stimulating adenovirus DNA replication. $E M B O$ I. 6: 3771-3778.

Prywes, R. and R.G. Roeder. 1987. Purification of the c-fos enhancer-binding protein. Mol. Cell. Biol. 7: 3482-3489.

Rosenberg, A.H., B.N. Lade, D.-S. Chui, S.-W. Lin, J.J. Dunn, and W. Studier. 1987. Vectors for selective expression of cloned DNAs by T7 RNA polymerase. Gene 56: 125-135.

Rüther, U. and B. Müller-Hill. 1983. Easy identification of cDNA clones. EMBO I. 2: 1790-1794.

Saffer, L. and O.L. Miller, Jr. 1986. Electron microscopic study of Saccharomyces cerevisiae rDNA chromatin replication. Mol. Cell. Biol. 6: 1148-1157.

Santoro, C., N. Mermod, P.C. Andrew, and R. Tjian. 1988. A family of human CCAAT-box-binding proteins active in transcription and DNA replication: Cloning and expression of multiple cDNAs. Nature 334: 218-224.

Sauer, R., D. Smith, and A. Johnson. 1988. Flexibility of the yeast $\alpha 2$ repressor enables it to occupy the ends of its operator leaving the center free. Genes Dev. 2: 807-816.

Siebenlist, U. and W. Gilbert. 1980. Contacts between Escherichia coli RNA polymerase and an early promoter of phage T7. Proc. Natl. Acad. Sci. 77: 122-126.
Smith, P.P. 1986. 'The control of the a specific gene for the alpha factor receptor in Saccharomyces cerevisiae: Studies on a lacZ fusion'. Ph.D. thesis. Cornell University, New York.

Sprague, G.F., Jr., R. Jensen, and I. Herskowitz. 1983. Control of yeast cell type by the mating type locus: Positive regulation of the $\alpha$-specific STE3 gene by the MAT 1 product. Cell 32: 409-415.

Stenlund, A., G.L. Bream, and M.R. Botchan. 1987. A promotor with an internal regulatory domian is part of the origin of replication in BPV-1. Science 236: 1666-1671.

Towbin, H., T. Stalhelin, and J. Grodon. 1979. Electrophoretic transfer of proteins from polyacrylamide gels to nitrocellulose sheets: Procedure and some applications. Proc. Natl. Acad. Sci. 76: 4350-4354.

Treisman, R. 1985. Transient accumulation of c-fos RNA following serum stimulation requires a conserved $5^{\prime}$ element and c-fos 3' sequences. Cell 42: 889-902.

- 1986. Identification of a protein-binding site that mediates transcriptional response of the $c$-fos gene to serum factors. Cell 46: 567-574.

- 1987. Identification and purification of a polypeptide that binds to the c-fos serum response element. $E M B O J$. 6: 2711-2717.

Wiederrecht, G., D.J. Shuey, W.A. Kibbe, and C.S. Parker. 1987. The Saccharomyces and Drosophila heat shock transcription factors are identical in size and DNA binding properties. Cell 48: 507-515.

Wilson, K.L. and I. Herskowitz. 1984. Negative regulation of STE6 gene expression by the $\alpha 2$ product of Saccharomyces cerevisiae. Mol. Cell. Biol. 4: 2420-2427. 


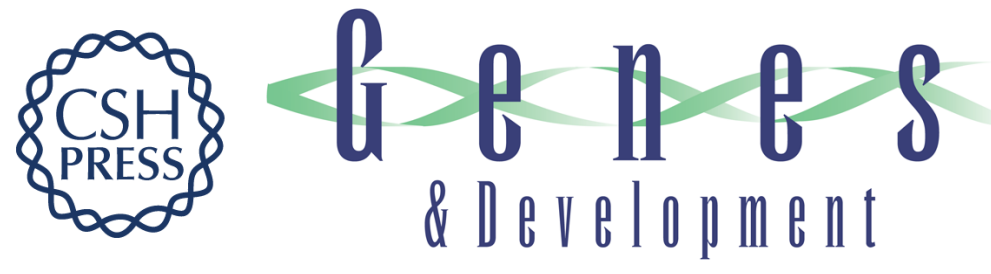

\section{A protein involved in minichromosome maintenance in yeast binds a transcriptional enhancer conserved in eukaryotes.}

S Passmore, R Elble and B K Tye

Genes Dev. 1989, 3:

Access the most recent version at doi:10.1101/gad.3.7.921

References This article cites 45 articles, 17 of which can be accessed free at:

http://genesdev.cshlp.org/content/3/7/921.full.html\#ref-list-1

License

Email Alerting

Service

Receive free email alerts when new articles cite this article - sign up in the box at the top right corner of the article or click here.

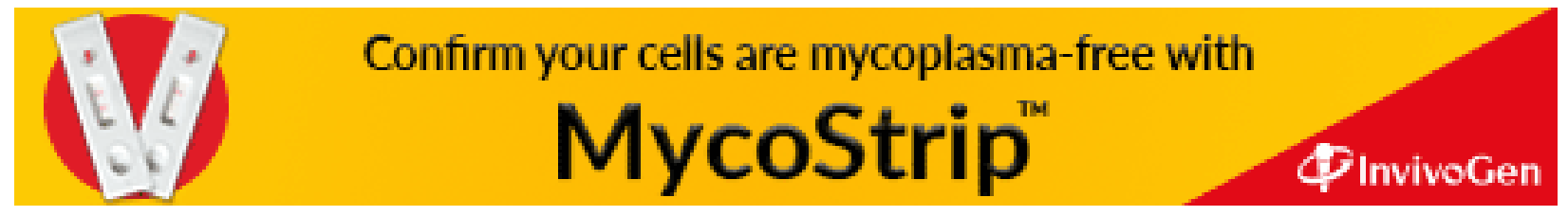

